\title{
Immunolocalisation of vasoactive intestinal peptide and substance $P$ in the developing gut of Dicentrarchus labrax (L.)
}

\author{
A. Pederzoli, I. Bertacchi, A. Gambarelli, L. Mola \\ Department of Animal Biology, University of Modena and Reggio Emilia, Modena, Italy
}

(C2004, European Journal of Histochemistry

This study was carried out on the sea bass (Dicentrarchus labrax) to follow, during development, the appearance and distribution of substance $P(S P)$ and vasoactive intestinal peptide (VIP), which act on gut motility. The results suggest that SP and VIP play an important role as neuromodulators, influencing the motility of the digestive tract starting from the early stages of gut development, even prior to exotrophic feeding. In the peptidergic nervous system, the appearance of immunoreactivity to SP began at the rectum and followed a distal to proximal gradient, whereas for VIP, it began proximally and progressed along a proximal to distal gradient. The two peptides also appeared in gut epithelial cells. In some regions, all the cells were positive. From this distribution of positive cells, we conclude that these peptides may also have other roles, besides being neurotransmitters in the enteric nervous system and hormones of the gastro-enteropancreatic system. VIP and SP might have paracrine and/or autocrine activity in the physiological maturation of the gut epithelium, as it has already been hypothesised for other peptides.

Key words: teleosts, sea bass, development, gut, VIP, SP, immunohistochemistry.

Correspondence: Lucrezia Mola, Dipartimento di Biologia Animale, via Campi 213/D, 41100 Modena, Italy.

Phone: international +39.059.2055535.

Fax: international +39.059.2055548.

E-mail: mola.lucrezia@unimore.it

Paper accepted on September 25, 2003

European Journal of Histochemistry

2004; vol. 48 issue 2 [Apr-Jun]: 179-184
I $\mathrm{n}$ recent years, much teleost research has focused on immunohistochemical localisation of regulatory peptides of the gut of adults (Langer et al., 1979; Holmgren et al., 1982; Rombout and Taverne-Thiele, 1982; Rombout and Reinecke, 1984; Rombout et al., 1986; Elbal and Aguillero, 1986; Elbal et al., 1988; Beorleugui et al., 1992; Pederzoli et al., 1996, Visus et al., 1996, 1998).

Instead, few studies have tracked the appearance of gut peptides in teleosts during development (L'Hermite et al., 1985; Garcìa Hernandez et al., 1994; Reinecke et al., 1997). Nonetheless, the period after hatching is one of the most interesting and variable. Teleost larvae, which are very small functionally independent vertebrates, undergo a daily increase in adaptability, and many organs differentiate and become active. These concerted processes require an early nervous and endocrine integration.

Our goal was to examine some features of the intramural nervous system during the early larval phases of Dicentrarchus labrax, a species of commercial interest of which the development of the gut and the ontogeny of the gastro-entero-pancreatic system (GEP) are known (Garcìa Hernandez et al., 1994; 2001). We carried out immunohistochemical tests to follow the appearance and distribution of substance $P$ (SP) and vasoactive intestinal peptide (VIP), which act on gut motility.

The distension of the intestine by a passing bolus generates two separate reflexes of the circular muscle layer; an ascending orally directed excitatory reflex and a descending anally directed inibitory reflex. A general pattern can be observed in mammals; the descending neurons often contain the relaxing agents nitric oxide ( NO) and/or VIP, whereas the ascending motor neurons use acetylcholine and SP or related peptides of the tachykinin group, as primary transmitters (Karila et al., 1998). Physiological and immunohistochemical experiments have made clear that many of these substances found in mammals also have an effect in the 
fish gastrointestinal canal (see Olsson and Holmgren, 2001).

\section{Materials and Methods}

Larvae of Dicentrarchus labrax (L.) at 2, 4, 12 and 18 days after hatching (respectively about 3, 5, 7 and $8 \mathrm{~mm}$ in length) were obtained from the aquaculture "Valle Figheri" fishfarm, Lova (Venice, Italy). In this fishfarm, the standard rearing conditions were: $24 \mathrm{~h}$ light photoperiod at $16-18^{\circ} \mathrm{C}$ temperature, and $40 \%$ salinity for the first 12 days. Subsequently, the salinity was lowered to $30 \%$. The diet consisted of rotifers supplied from days 5 to 16 and newly hatched Artemia starting from day 10.

Specimens (20 for each stage) were fixed in toto in Bouin's fluid, embedded in paraffin and cut in 7 $\mu \mathrm{m}$ transversal sections.

Some slides for each stage were processed with hematoxylin-eosine for light microscopic examination of the normal alimentary architecture, and the other slides for each stage were processed with the biotin-avidin immunohistochemistry technique utilising the following polyclonal antibodies from rabbit: anti SP (Cambridge Research Biochemical, U.K.) titer 1:500; anti VIP (Amersham, U.K.) titer $1: 500$.

Slides were rinsed three times in $0.01 \mathrm{M} \mathrm{PBS}, \mathrm{pH}$ 7.4 and incubated for $30 \mathrm{~min}$ in $0.3 \% \mathrm{H}_{2} \mathrm{O}_{2}$ to block endogenous peroxidase activity, then placed in PBS containing $0.3 \%$ Triton X-100 and blocked with $5 \%$ normal goat serum (DAK0, Denmark) for $30 \mathrm{~min}$. The slides were incubated with the primary antibody in a moist chamber at $4^{\circ} \mathrm{C}$ overnight (40 hours for anti-SP). Subsequently, they were rinsed with PBS and incubated for $30 \mathrm{~min}$ at room temperature with the secondary biotinylated goat antirabbit antibody (titer 1:300) (DAK0, Denmark). After rinsing in PBS and $0.1 \mathrm{M}$ Tris $\mathrm{pH}$ 7.6, the prepations were incubated with avidin-biotin complex (ABC, Vector, Vectastain, Burlingame, $C A$, USA) in Tris for $45 \mathrm{~min}$ at room temperature. The reaction was visualized with $3,3^{\prime}$-diaminobenzidine tetrahydrochloride (10 mg/15 mL Tris) (Sigma). Immunostaining was allowed to develop in 4-10 min with $10-12 \mathrm{~mL}$ of $30 \% \mathrm{H}_{2} \mathrm{O}_{2}$.

The specificity of the reactions was checked by omitting the primary antibodies or by preadsorbing them in liquid phase with the homologous antigens (50 $\mathrm{mg} / \mathrm{mL}$ diluted antiserum). All sections were rinsed in Tris and aqua fontis dehydrated and mounted in Eukitt, and observed in a Zeiss Axioscop microscope, according to Nomarski.

\section{Results}

\section{2-day-old specimens}

The gut of these larvae was undifferentiated and still closed at both limbs; no immunoreactivity (IR) to immunohistochemical reactions was detected.

\section{4-day-old specimens}

These larvae presented a buccal aperture but the gut was still at an early stage of differentiation. The pharynx led into the alimentary canal, in which three regions were discernible: a cephalic region with stratified epithelium and narrow lumen, a mid region with simple columnar epithelium and larger lumen, and a valve structure opening into the rectum, which terminated in a cul de sac. Though differentiation was minimal, all epithelial cells positive to SP (Figure 1a) were observed in the cephalic region. VIP-positive fibers were present in the fold axis of the cephalic (Figure $1 b$ ) and mid region.

\section{2-day-old specimens}

In these specimens the gut appeared differentiated into various regions: pharynx, oesophagus, stomach and intestine. The intestinal epithelium was raised into folds that decreased in height proceeding caudally, up to at the valve structure that was well differentiated at this stage. In the rectum, the lumen became wide and the epithelium gradually flattened, terminating in the anal aperture. Numerous epithelial cells immunopositive to SP were present, but only in the oesophageal region (Figure 1c). Nerve cells immunoreactive to SP were present in the wall of the posterior gut. Nerve fibers intensely positive to VIP were identified in the gut wall (adjacent to the epithelium) of the oesophageal region (Figure $1 d$ ). This IR decreased in intensity caudally and was absent in the intestine.

\section{8-day-old specimens}

In these specimens the general morphology of the gut did not differ significantly from that of the previous stage. Epithelial cells immunoreactive to SP were present in limited numbers in the pharynx, whereas they were well represented in the oesophagus; in the stomach, these cells appeared concentrated in the ventral region (Figure $2 \mathrm{a}$ ) and then thinned out, disappearing in the anterior intestine 

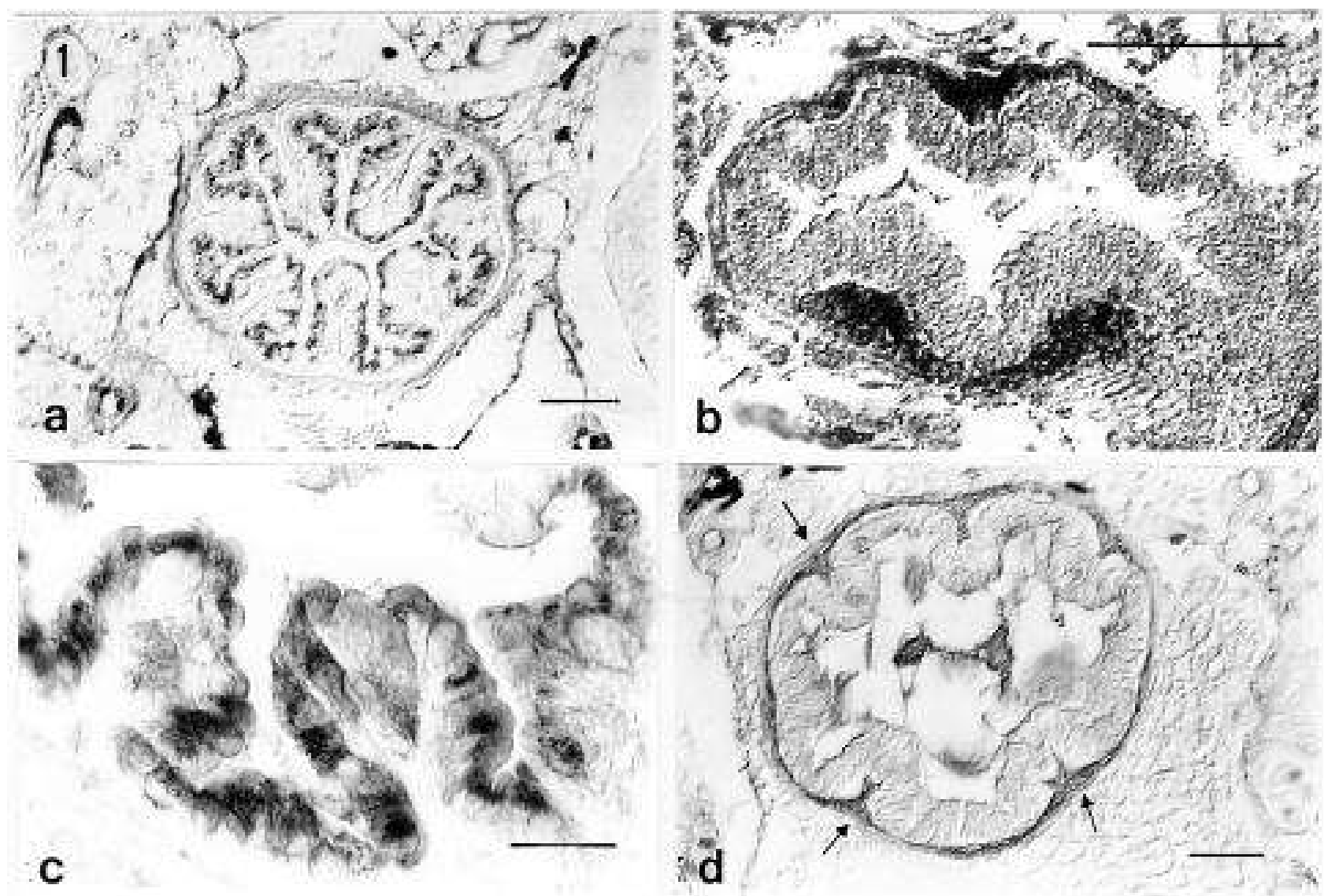

Figure 1. Transversal sections of gut in 4-day-old (a,b) and 12-day old (c,d) specimens of D/centrarchus labrax: a) immunoreactivity to SP (1:500) in many epithelial cells of the cephalic region. b) Fibers immunopositive to VIP (1:500) in the fold axis of the cephalic region; c) esophageal epithelium with numerous positive cells to anti SP (1: 500). d) Nerve fibers (arrows) positive to anti VIP (1: 500 ) in the wall of the oesophageal region. Bar $=\mathbf{5 0} \boldsymbol{\mu m}$. Interference light microscopy according Nomarski.

only to reappear in the rectum. At the posterior intestine and rectum, neurons positive to SP appeared in the wall (Figure 2c, d). Imunoreactivity to VIP was localised in nerve fibers from the oesophagus to the end of the intestine. Moreover, many epithelial cells immunopossitive to VIP appeared in the stomach and duodenum; in some tracts, all the cells of a section showed VIP-IR (Figure 2b).

The controls obtained by omitting the primary antibodies or preadsorbing them in liquid phase with the homologous antigens were negative.

\section{Discussion}

It is known that larval development in fish is strictly dependent on breeding conditions, such as temperature, salinity and photoperiod (Blaxter, 1988). In particular, the hatching rates and the hatching time of D. labrax eggs are strongly influ- enced by a small difference in temperature $\left(2^{\circ} \mathrm{C}\right)$ (Saka et al., 2001). Under the conditions used at "Valle Figheri", 4-day-old larvae, though bearing an evident yolk sac, already had a mouth, whereas 18-day-old larvae had just completed resorption of the yolk sac. These features led to the choice of the stages, with the aim of correlating the appearance of VIP and SP with morphological differentiation and/or transition to exotrophic feeding. Four phases have been described by Garcìa Hernandez et al. (2001) for developing gut in the sea bass: phase I, a lecitotrophic period from hatching to the opening of the mouth; phase II, a lecitoexotrophic period from the opening of the mouth to the complete resorption of the yolk sac; phase III, an exclusively exotrophic period from the complete resorption of the yolk to the appearance of the first gastric glands; phase IV, from the appearance of the first gastric glands onwards. Thus, in this study we examined the phases I-II-III. 

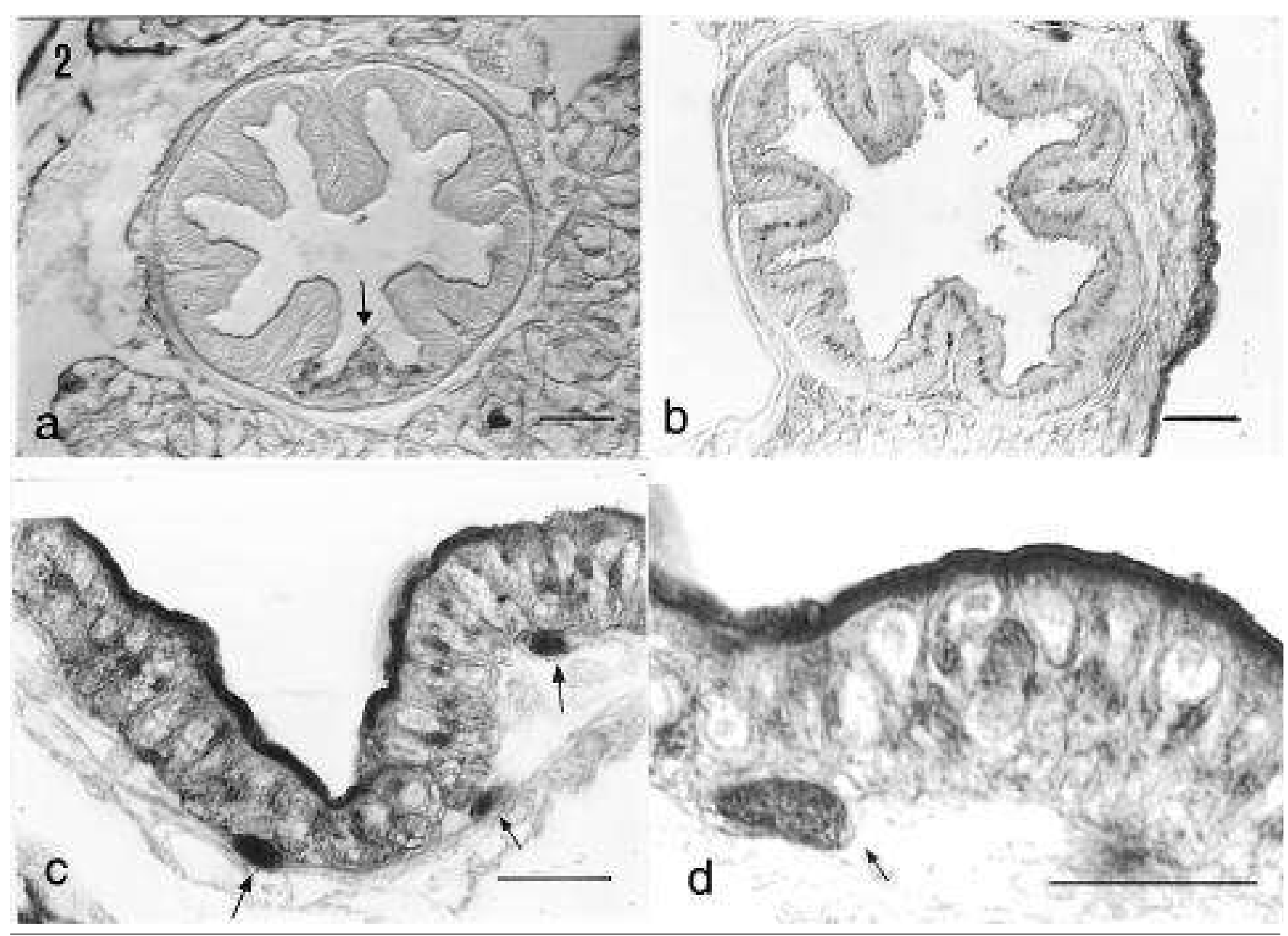

Figure 2. Transversal sections of gut in 18-day-old specimens of Dicentrarchus labrax: a) Cells (arrow) immunopositive to SP (1:500) concentrated in the ventral region of the stomach. b) Duodenum with epithelial cells immunoreactive to VIP (1:500). c, d) Neurons immunoreactive to SP (1:500) in wall of terminal gut (arrows). Bar $=\mathbf{5 0} \mu \mathrm{m}$. Interference light microscopy according Nomarski.

Studies evaluating the appearance of the capacity to absorb lipids and proteins during transition to the exotrophic phase in D. labrax have demonstrated the importance of a diet based on Artemia and shrimps over artificial feeding in promoting adequate gut development (Deplano et al., 1991 a, b). Thus, we believe that the present results, obtained from larvae fed with Artemia and rotifers, describe a picture that more closely reflects development in a natural environment.

Tachykinins-IR has been demonstrated in the gastrointestinal tract of all vertebrates (see Jensen and Holmgren, 1994). In the context of this family of peptides, SP has been localised in the neurons of the myenteric plexus and circular muscle layer of the Atlantic cod (Karila et al., 1998). VIP immunoreactive nerve cell bodies are found in the myenteric plexus of most vertebrates investigated, including teleosts; the submucosal plexus of teleosts presents only VIP-positive fibers (see Olsson and
Holmgren, 2001). A general pattern that emerges is that the descending inhibitory reflex pathway often uses VIP/PACAP and N0, whereas the excitatory ascending way uses SP or related tachykinins (Olsson and Holmgren, 2001).

During development of the sea bass, VIP-IR appears in nerve fibers of the anterior gut region from 4 days after hatching, whereas SP-IR appears in the neurons of the terminal region from 12 days after hatching. As development progresses, IR for these two peptides extends to other regions. Our data on the gut of the sea bass allow us to assert that the appearance of SP in the peptidergic nervous system begins from the rectum and follows a distal to proximal gradient, whereas VIP-IR begins proximally and progresses along a proximal to distal gradient.

The present results suggest that SP and VIP play an important role as neuromodulators, influencing the motility of the digestive tract from the early 
stages of development of D. labrax. Even to 5-HT, present in the epithelium of the presumptive rectum of the same species before exotrophic feeding, has been assigned a role as a chemical inductor of motility during development (Garcìa Hernandez et al., 1994). The expression of the molecules involved in intestinal motility thus begins prior to exotrophic feeding.

The two peptides examined here also appear in gut epithelial cells. As a rule, the gastrointestinal hormones are produced in some cells of the GEP, localised between epithelial cells. Instead, in our specimens, SP-IR was detected from 4 days after hatching in all epithelial cells of the cephalic region; successively SP-IR extended to other regions of the gut and particularly in the rectum. VIP-IR is detected in all epithelial cells of the stomach at 18 days after hatching. Thus, for the distribution of IR-cells, we conclude that these molecules may also have other roles besides those of neurotransmitters of the enteric nervous system and hormones of the GEP system. The appearance of SP and VIP in epithelial cells even in 4-day-old specimens and 18-day-old specimens, respectively, may suggest that these substances also have paracrine and/or autocrine activity in the physiological maturation of the gut epithelium. A regulatory activity on cell growth in the gut has been hypothesised for other peptides, such as glucagon (Jasleen et al., 2000) and peptide YY (Mannon, 2002).

\section{Funding}

This research was supported by MIUR grant (ex $60 \%$ ) to L. Mola. The authors are grateful to Dr. Attilio Spanò of the "Valle Figheri" fishfarm, Lova (Venice, Italy) for providing the specimens used in this research.

\section{References}

Blaxter JHS. Pattern and variety in development. In: Hoar WS, Randall DJ, eds. Fish physiology, vol. 11. Academic Press, London, 1988. p. 1-58.

Beorlegui C, Martinez A, Sesma P. Endocrine cells and nerves in the pyloric ceca and the intestine of Oncorhyncus mykiss (Teleosts): an immunocytochemical study. Gen Comp Endocrinol 1992;86:48395.

Deplano M, Diaz JP, Connes R, Kentouridivanach M, Cavalier F. Appearance of lipid absorption capacities in larvae of the sea bass Dicentrarchus labrax during to the exotrophic phase. Mar Biol 1991;108:361-71.

Deplano M, Connes R, Diaz JP, Barnabe G. Variation in the absorption of macromolecular proteins in larvae of the sea bass Dicentrarchus labrax during to the exotrophic phase. Mar Biol 1991;110:29-36.
Elbal MT, Aguilleiro B. An immunocytochemical and ultrastructural study of endocrine cells in the gut of a teleost fish, Sparus auratus L. Gen Comp Endocrinol 1986;64:339-54.

Elbal MT, Lozano MT, Aguilleiro B. The endocrine cells in the gut of Mugil saliens risso, 1810 (Teleosts): an immunocytochemical and ultrastructural study. Gen Comp Endocrinol 1988;70:231-46.

Garcìa Hernandez MP, Lozano MT, Agulleiro B. Ontogeny of some endocrine cells of the digestive tract in sea bass (Dicentrarchus labrax L.): an immunocytochemical study. Cell Tissue Res 1994; 277:373-83.

Garcìa Hernandez MP, Lozano MT, Elbal MT, Agulleiro B. Development of the digestive tract of sea bass (Dicentrarchus labrax L.). Light and electron microscopic studies. Anat Embryol 2001; 204:39-57.

Langer M, Van Noorden S, Polak JM, Pearse AGE. Peptide hormonelike immunoreactivity in the gastrointestinal tract and endocrine pancreas of eleven teleost species. Cell Tissue Res 1979;199:493508.

L'Hermite A, Ferrand R, Dubois MP, Andersen AC. Detection of endocrine cells by immunofluorescence method in the gastroenteropancreatic system of adult eel, glass-eel, and leptocephalic larva (Anguilla anguilla L.). Gen Comp Endocrinol 1985;58:347-59.

Holmgren S, Vaillant C, Dimaline R. VIP-, substance P-, gastrin/CCK, bombesin-, somatostatin-, and glucagon-like immunoreactivities in the gut of the rainbow trout, Salmo gairdneri. Cell Tissue Res 1982; 223:141-53.

Jasleen J, Shimoda N, Shen ER, Tavakkolizadeh A, Whang EE, Jacobs D0, Zinner MJ, Ashley SW. Signaling mechanisms of glucagon-like peptide 2-induced intestinal epithelial cell proliferation. J Surg Res 2000;90:13-8.

Jensen J, Holmgren S. The gastrointestinal canal. In: Olsson C, Holmgren S, eds. Comparative physiology and evolution of the autonomic system. Harwood Academic, Churchill, 1994. p. 119-67.

Karila P, Shahbazi F, Jensen J, Holmgren S. Projections and actions of tachykininergic, cholinergic, and serotoninergic neurones in the intestine of the Atlantic cod. Cell Tissue Res 1998;291:403-13.

Mannon PJ. Peptide $Y Y$ as a growth factor for intestinal epithelium. Peptides 2002;23:383-8.

Olsson C, Holmgren S. The control of gut motility. Comp Biochem Physiol A 2001;128:481-503.

Pederzoli A, Trevisan P, Bolognani Fantin AM. Immunocytochemical study of endocrine cells in the gut of goldfish Carassius carassius (L.) var. auratus submitted to experimental lead intoxication. Eur J Histochem 1996; 40:305-14.

Reinecke M, Muller C, Segner H. An immunohistochemical analysis of the ontogeny, distribution and coexstence of 12 regolatory peptides and serotonin in endocrine cells and nerve fibers of the digestive tract of the turbot, Scophthalmus maximus (Teleosts). Anat Embryol 1997;195:87-102.

Rombout JHWM, Taverne-Thiele JJ. An immunocytochemical and electronmicroscopical study of endocrine cells in the gut and pancreas of a stomachless teleost fish, Barbus conchonius (Cyprinidae). Cell Tissue Res 1982;203:9-23.

Rombout JHWM, Reinecke M. Immunocytochemical localization of (neuro)peptide hormones in endocrine cells and nerves of the gut of a stomachless teleost fish, Barbus conchonius (Cyprinidae). Cell Tissue Res 1984;237:57-65.

Rombout JH, Grinten CPM van der, Peeze Binkhorst FM M, TaverneThiele JJ, Schooneveld H. Immunocytochemical identification and localization of peptide hormones in the gastro-entero-pancreatic (GEP) endocrine system of mouse and a stomachless fish, Barbus conchonius. Histochemistry 1986;84:471-83.

Saka S, Firat K, Kamaci HO. The development of european sea bass (Dicentrarchus labrax L., 1758) eggs in relation to temperature. Turkish J Veterinary Anim Sci 2001;25:139-47.

Visus IG, Abad ME, Garcìa Hernàndez MP, Agulleiro B. Occurence of somatostatin and insulin immunoreactivities in the stomach of sea bass (Dicenrtrarchus labrax L.): light and electron microscopic studies. Gen Comp. Endocrinol 1996;102:16-27.

Visus IG, Garcìa Hernàndez MP, Lozano MT, Agulleiro B. Glucagonand NPY-related peptide-immunoreactive cells in the gut of sea bass (Dicenrtrarchus labrax L.): a light and electron microscopic studiy. Gen Comp Endocrinol 1998;112:26-35. 
A. Pederzoli et al. 